\title{
Sustainable Energy Maintaining into Local Development Plan in Nepal
}

\section{Raj Sigdel E*}

Environment Specialist, Local Governance and Community Development Program, Nepal

\begin{abstract}
Over $50 \%$ of Nepal's economy depends on natural resources. Environment and poverty issues are linked closely. Therefore, Nepal needs to follow sustainable development path that takes an account of poor as well as contributes to sustainable development of environment. Many poor women and children suffer from respiratory problems related to indoor air pollution and suffer lack of economic opportunities due to lack of energy access. Sustainable energy management could be a viable strategy to address twin objectives of poverty alleviation and environment management. Effective management of national energy sector and energy development and expansion in rural areas will contribute directly in the improvement of the overall rural population's living standard through maintaining ecological balance, save time in collection of fuel wood, generate additional employment opportunities, improve health and increase access to education to rural children. Sustainable development depends in large measure on successfully integrating environment and energy into economic planning and decision-making, a process known as environmental mainstreaming. Successful mainstreaming can be achieved only when the pro-poor environmental linked alternative energy program and activities are adequately incorporated in socio-economic development plan and programs of local bodies.

While reviewing 15 District and five Municipal Annual Development Plans, it was revealed that 95\%local bodies have considered environment as a major program in their annual development plan. Only $50 \%$ local bodies have included alternative energy management program in this annual development plans. Moreover, less than $1 \%$ program as well as budgets of the studied District Development Committee and Municipalities were directed towards addressing the energy demands of local communities. To better address the environment in general and energy in particular issues it is imperative further enhance the capacity of local bodies.
\end{abstract}

Keywords: Sustainable energy; Local development plan; Natural resources; Rural areas; Nepal

\section{Introduction}

Over $50 \%$ of Nepal's economy depends on natural resources. Ever increasing population growth and income poverty, the very resources are being depleted day by day. Almost one quarter of Nepal's 34 million population lives below $\$ 1.25$ a day (World Bank 2010/11). Significant proportion of deforestation in Nepal is linked with the dependency on forest resources for energy supply. In addition to the lack of alternative means of energy, lack of local knowledge on energy saving devices and scarcity of fuel wood in trans-Himalayan region are the major issues of concern. In this context, Nepal needs sustainable energy program that should aim to reduce stress on critical resources primarily forests through wider use of electricity and other alternative energy programs.

Environment and poverty issues are linked closely. Therefore, Nepal needs to follow sustainable development path that takes an account of poor as well as contributes to sustainable development of environment. Many poor women and children suffer from respiratory problems related to indoor air pollution and suffer lack of economic opportunities due to lack of energy access. Nepal accounts for the lowest share of commercial energy (around $500 \mathrm{kWh}$ per capita per year) among all South Asian countries. Of the 3915 VDCs, only 339 are fully electrified and another 1077 partially electrified. About 1,669,782 of 4174,457 households (40\%) have access to electricity. Seven percentage of people with electricity access use alternative energy such as solar power, biogas and micro hydro. Many poor households face the impact of drought and floods which are likely to worsen with climate change. Nepal is one of 10 most disaster prone countries in the world.

\section{Nepal's commitment towards environment conservation}

The Interim Constitution (2007) of Nepal recognized the 'right to live in a clean environment' for every individual. The Interim Constitution adopted policies to maintain a clean environment and to avoid the adverse effects of physical development activities on the environment. The Forestry Sector Policy, 2000, prioritizes biodiversity conservation while ensuring both sustainable livelihoods for people and a landscape planning approach to manage biodiversity on an ecological basis. The Local Self-Governance Act of 1999 empowers District Development Committees (DDCs) and Village Development Committee (VDCs) to collect revenues from local resources, including from natural resources, and called on each local government unit to draw up a development plan of its own. The Sustainable Development Agenda for Nepal (SDAN) envisages integrating environment and development in the national policymaking and planning framework by stressing public participation in ecosystem conservation at the landscape. The Environment Protection Act enacted in 1996 is the umbrella legislation for environmental protection in Nepal. This Act aims to ensure sustainable development through the integration of environment and development, the sustainable use of natural resources, and the creation of a clean and healthy environment for all people in Nepal. The three year plan (2010/11-2012/13) (TYP) was formulated within a long-term vision of transforming the country from least developed country status to that of a developing country. The TYP strategy places importance on generating employment opportunities,

*Corresponding author: Raj Sigdel E, Environment Specialist, Local Governance and Community Development Program, Nepal, E-mail: ekrajsigdel@hotmail.com

Received June 27, 2013; Accepted September 19, 2013; Published Septemeber 23, 2013

Citation: Raj Sigdel E (2013) Sustainable Energy Maintaining into Local Development Plan in Nepal. J Biodivers Endanger Species 1: 112. doi: $10.4172 / 2332-2543.1000112$

Copyright: @ 2013 Raj Sigdel E. This is an open-access article distributed under the terms of the Creative Commons Attribution License, which permits unrestricted use, distribution, and reproduction in any medium, provided the original author and source are credited. 
reducing poverty, improving food security and addressing the challenges of environment degradation and climate change.

\section{Alternative energy for environment management and poverty alleviation}

It can be concluded from the aforementioned information that environment and poverty are closely linked. Sustainable energy management could be a viable strategy to address twin objectives of poverty alleviation and environment management. There are huge possibilities of producing energy in Nepal. Availability of enormous water resources and topographic situation gives rise to a potential for 83,000 MW of hydropower of which about 43,000 MW of power production seems to be economically and technically feasible. Till now, where only about $563 \mathrm{MW}$ has been harnessed which is mainly consumed in urban areas, the rural and remote areas of the nation has no access to reliable and clean energy. In the other hand, in spite of enough possibility of producing energy in rural areas in the form of biogas, solar energy, wind energy, improved water mill micro and mini hydropower, it has not been used as per the needs.

In Nepal, only 160,000 biogas plants have been installed out of the installation potential of 1.9 million biogas plants. There has been savings in the energy consumption by installing 250,000 improved cooking stoves. Similarly, in spite of huge potential of solar energy, only 75,000 solar home systems have been installed. With regard to the wind energy, it has not been possible to harness its potential. Up to now about 2,000 traditional water mills have been improved. Only about 8 MW power is produced through micro hydro. These efforts have made it possible to provide electricity services to about 40 percent of the population in the country. In the rural areas, only 29 percent of the population has access to electricity. In total, 74.4 of energy is supplied from traditional biomass such as firewood and cow dung Table 1. It has been recorded that more than 7,500 deaths/year are caused due to indoor air pollution. To date 637,000+; mud and metallic improved cooking stoves are being adopted in Nepal. Similarly, 280,000+ and $600+$ biogas and solar cookers respectively are being used in Nepal.

Since, 86 percent of the energy consumed in rural areas comes from the traditional sources, which results on environmental degradation and there has been reduction in agricultural production due to reduction in productivity of agricultural land because of use of dung and agricultural residues. There has also been adverse impact on the health of rural population mainly women and children because of use of traditional energy resources. Similarly, rural children are also deprived of opportunity of education, as they have to spend most of time in collecting such energy source. In this context, there is ample possibility of improving the living standards of rural population by developing environment- friendly energy resources in rural areas by making

\begin{tabular}{|c|c|c|c|c|}
\hline Region and share & Total HHs & Fire-wood & Cow Dung & $\begin{array}{c}\text { Firewood + } \\
\text { Cow Dung }\end{array}$ \\
\hline Mountain & 363,698 & 344,843 & 1,517 & $\mathbf{3 4 6 , 3 6 0}$ \\
\hline$\%$ share & $6.70 \%$ & $94.80 \%$ & $0.40 \%$ & $\mathbf{9 5 . 2 0 \%}$ \\
\hline Hill & $2,532,041$ & $1,696,376$ & 2,810 & $\mathbf{1 , 6 9 9 , 1 8 6}$ \\
\hline$\%$ share & $46.70 \%$ & $67.00 \%$ & $0.10 \%$ & $\mathbf{6 7 . 1 0} \%$ \\
\hline Terai & $2,527,558$ & $1,429,005$ & 558,799 & $\mathbf{1 , 9 8 7 , 8 0 4}$ \\
\hline$\%$ share & $46.60 \%$ & $56.50 \%$ & $22.10 \%$ & $\mathbf{7 8 . 6 0} \%$ \\
\hline Nepal & $5,423,297$ & $3,470,224$ & 563,126 & $\mathbf{4 , 0 3 3 , 3 5 0}$ \\
\hline$\%$ share & & $\mathbf{6 4 . 0 0} \%$ & $\mathbf{1 0 . 4 0 \%}$ & $\mathbf{7 4 . 4 0 \%}$ \\
\hline
\end{tabular}

Source: National Population and Housing Census, 2011 (CBS, 2012)

Table 1: Use of fire wood and cow dung for energy. financially affordable to reduce dependency on traditional and fossil fuel resources. Effective management of national energy sector and energy development and expansion in rural areas will contribute directly in the improvement of the overall rural population's living standard through maintaining ecological balance, save time in collection of fuel wood, generate additional employment opportunities, improve health and increase access to education to rural children. Sustainable development depends in large measure on successfully integrating environment and energy into economic planning and decision-making, a process known as environmental mainstreaming. Successful mainstreaming can be achieved only when the pro-poor environmental linked alternative energy program and activities are adequately incorporated in socioeconomic development plan and programs of local bodies.

\section{Objectives}

The general objective of the study was to review whether local bodies are considering pro-poor environmental linked alternative energy program and activities in their socio-economic development plan and programs. The specific objective of the study was to; assess to what extent local bodies are formulating energy related programs and budgets in their annual development plan and to recommend measure how the upcoming annual development plans will be more environment and energy friendly. An important goal of the study was to help policy makers arrive at viable, informed policy choices, to provide a better understanding of the policymaking process and to supply decision makers with reliable policy-relevant knowledge about pressing environment, economic and social problems.

\section{Methodology}

It is to review whether the DDCs have environment, climate change and disaster management into their programs and allotted sufficient budget to achieve those activities. To achieve the above mentioned objectives, policies, programs and budget for three years, 15 Districts Development Committees and 5 municipalities representing different ecological regions such as High Mountain, Middle Mountain, Inner Terai and the Terai, are selected and analyzed. And also the proportion and linkage of budget spent in the environmental sector including the disadvantages communities such as women, dalits and indigenous people to the total budget can also be interpreted.

The DDCs selected are from 15 districts namely Jhapa, Solokhumbu, Udaypur, Sarlahi, Chitawan, Rashuwa, Lalitpur, Manang, Parbat, Nawalparashi, Banke, Surkhet, Jumla, Doti, and kanchanpur. The five municipalities are: Dhangadi, Daang, Lekhanath, Bhaktapur and Dharan Table 2. In this assignment, a comprehensive report is prepared and presented to review the three year policies and budget of these districts and municipalities during 2068/69, 2069/70 and 2070/71 and presented to Environment Division of Ministry of Federal Affairs and Local Development (MoFALD). The annual development plans for 2070/71 of some of the selected districts could not be analyzed due to unavailability of report in the Ministry. The article summaries key features of the study report.

\begin{tabular}{|c|c|c|c|c|c|}
\hline $\begin{array}{c}\text { Districts I } \\
\text { Municipality }\end{array}$ & Central & East & Mid-west & Western & Far-west \\
\hline Terai & $\begin{array}{c}\text { Sarlahi, } \\
\text { Chitwan }\end{array}$ & $\begin{array}{c}\text { Jhapa, } \\
\text { Dharan }\end{array}$ & $\begin{array}{c}\text { Banke, } \\
\text { Ghorahi }\end{array}$ & Nawalparasi & $\begin{array}{c}\text { Kanchanpur, } \\
\text { Dhangadi }\end{array}$ \\
\hline Midhill & $\begin{array}{c}\text { Madhyapur, } \\
\text { Lalitpur }\end{array}$ & Udaypur & Surkhet & $\begin{array}{c}\text { Parbat, } \\
\text { Lekhnath }\end{array}$ & $\mathrm{Na}$ \\
\hline Mountain & Rasuwa & Solukhumbu & Jumla & Manang & Doti \\
\hline
\end{tabular}

Table 2: Selected local bodies and their distribution. 
Citation: Raj Sigdel E (2013) Sustainable Energy Maintaining into Local Development Plan in Nepal. J Biodivers Endanger Species 1: 112. doi: 10.4172/2332-2543.1000112

Page 3 of 7

\section{Result}

While reviewing 15 District and five Municipal Annual Development Plans, it was revealed that 95\%local bodies have considered environment as a major program in their annual development plan. The environment program includes various activities such as establishing and strengthening of environment management units, environment management fund, and alternative energy programs. The other activities under environment headings comprises of agriculture, biodiversity conservation, forest management, climate change adaptation, repair and maintenance fund for rural roads and soil conservation and watershed management.

While assessing, consistency between approved programs and activities, as shown in Table 3 it was found that 95\% activities under environment programs are kept under funding category. Similarly, 70\%, $80 \%$ and $45 \%$ activities under disaster, sanitation and social inclusion respectively are being placed under funding headings.

While analyzing the budgeted activities in the annual development plans, out of the total approved Rs.62,87,39,68,111 (US\$ 698599646) (for entire budgets of the selected district and municipalities only $4.1 \%$ budgets are allocated for environment management activities, mainly for plantation, alternative energy, climate change adaptation and disaster risk management. The total budget allocated for alternative energy was less than $1 \%$. The budget figure is in decreasing order from terai to mid hills and mountain areas Figure 1. But it is opposite for GESI.

According to the Figure 1, environmental as well as disaster related activities are being budgeted in Terai regions, while the expenditure in mid hills and mountain regions for those activities are being decreased. Activities related to sanitation are implemented across the country while the gender and social inclusion activities are confined only in mid-hills and mountains. Good amount of budgets are allocated in environment and disaster activities in west and far west region. Over and above, there is no specific pattern of expenditure in terms of geographic region.

As shown in Figure 2, environment and disaster programs are being designed across the country with higher proportion in west and far west

\begin{tabular}{|c|c|c|c|c|}
\hline Program and Activities & Environment & Disaster & Sanitation & GESI \\
\hline $\begin{array}{c}\text { Program in annul plan of } \\
\text { local bodies (\%) }\end{array}$ & 95 & 75 & 90 & 80 \\
\hline $\begin{array}{c}\text { Activities in annul plan of } \\
\text { local bodies (\%) }\end{array}$ & 95 & 70 & 80 & 45 \\
\hline
\end{tabular}

Table 3: Approved programs and budgeted activities under pro-poor environmental activities. region.

According to Figure 3, in an average budget allocated for over all pro-poor environmental activities was around $8 \%$ of the total. Budgets allocated in different sub-activities are not consistent. For instance, budget for disaster was highest in 2068. However in the ensuing years it was more than five times lower. Similarly, budget for environmental activities was in fluctuation. Having heavy rainfall followed by flood in Terai in 2009, local bodies might have allocated more budgets for disaster risk management in 2010 or 2068.

Though 75\% studied local bodies have included disaster program in their annual development plans, budget has been allocated only for $20 \%$ of the total. In total, $50 \%$ and $60 \%$ local bodies have included program of alternative energy and disaster respectively in their annual development plans. Only 35\% studies local bodies (15 DDC and 5 Municipality) has included program of climate change adaptation in their annual development plan of which only Lekhnath Municipality has got funding for climate change adaptation activity thus far Annexure 1.

\section{Environment Mainstreaming into Local Development Plan}

Local government planning and budgeting: The current local government system consists of 75 Districts 3915 Village Development Committees, and 58 Municipalities There has been no local election for over a decade and local decision-making is undertaken by the District Development Committee (DDC), Village Development Committee (VDC) and Municipality. A VDC (made up of 9 wards) formulates a Village Development Plan (VDC Annual Plan) which is reviewed and approved by the VDC council. The approved Village Development Plan is channelled through the Elaka (cluster of villages or sub district) to

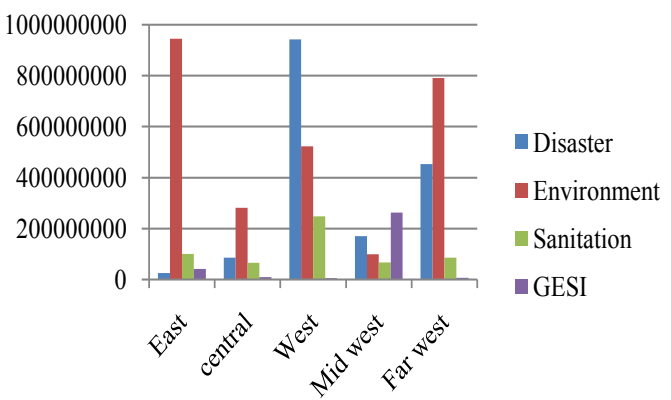

Figure 2: Development region wise sectoral programs.

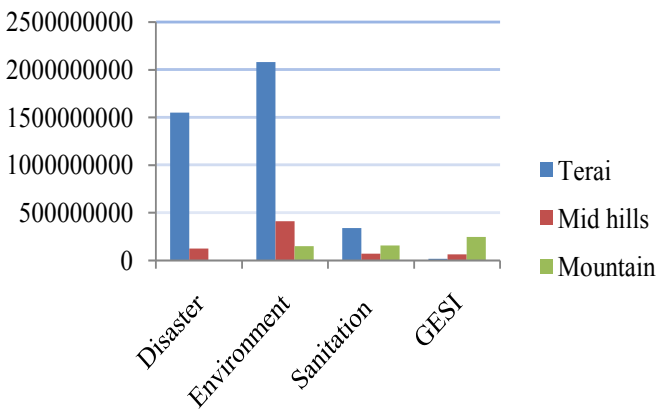

Figure 1: Geographic Region Wise Sectoral Investment.

\section{is channelled through the Elaka (cluster of villages or sub district) to}

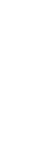


Citation: Raj Sigdel E (2013) Sustainable Energy Maintaining into Local Development Plan in Nepal. J Biodivers Endanger Species 1: 112. doi: 10.4172/2332-2543.1000112

the respective via subject committee to DDC. The DDC formulates a District Development Plan (DDC Annual Plan) which is approved by the DDC Council, represented by party representatives, civil society organizations, line agencies, private sectors and DDC officials. A new directive on Integrated Planning was introduced as a result of 1999 Local Self Governance Act. The DDC is expected to prepare plan formulation guidelines for VDCs and organize a pre-planning workshop at DDC level. LSGA brought positive changes in terms of VDC's access to budget resources and transparency in planning and decision-making process. Minimum Conditions and Performance Measures and public hearings at VDC level have proved to be effective incentive measures to enhance local accountability and performance in planning and budgeting. However the concept of true integrated planning still needs to be understood and practiced at the DDC, Municipality and VDC level.

\section{Result}

1. The officials in the local governance (DDCs, and Municipalities) have clearly addressed the problems of pro-poor environmental activities including environment, disaster, sanitation and gender and social inclusion. About $8 \%$ of the total budgets were allocated for overall propoor and inclusive environment development activities and only $4.1 \%$ set aside for environment development activities. Moreover less than $1 \%$ of the total annual development budgets have been allocated for alternative energy promotional activities. However, there is no definite trend in increasing or decreasing in the DDC plans and budgets.

2. Though the country has given higher priority to gender and social inclusion, the budget allocated annually by local bodies in this sub sector is only around $1 \%$ of the total budget.

3. Only $50 \%$ local bodies have included alternative energy management program in this annual development plans.

\section{Recommendations}

1. To ensure sustainable energy development, budget for pro-poor environment including genders and social inclusion and sanitation should be increased substantially in the ensuing years and budget for alternative energy should also be increased significantly in the years to come.

2. Enhance the capacity of local bodies to make their annual program and activities more consistent and be guided by long term plan instead of considering planning process as an ad hoc basis exercise

3. Demands should be created from grass root level communities for including more pro-poor environmental activities in local bodies' annual development plan and programs.

4. Increase the proportion of local bodies' annual development plan that consist alternative energy as a major program.

\section{Annexure 1: Policy, program and budgeted activities of local bodies}

\begin{tabular}{|c|c|c|c|}
\hline Districts/Municipalities & Policies/programs & Budgeted activities & Remarks \\
\hline Jhapa & $\begin{array}{l}\text { 1. Environment: Alternative and renewable energy policy, } \\
\text { repair and maintenance of road, elephant people conflict, } \\
\text { biodiversity conservation, bio-engineering, infrastructure } \\
\text { (6 programs) } \\
\text { 2. Sanitation: Health, ODF, drinking water, sanitation } \\
\text { (4 programs) } \\
\text { 3. Social Inclusion: Children, women, indigenous } \\
\text { people, disabled people, madheshis, muslims, dalits and } \\
\text { disadvantaged groups, poverty reduction, income and } \\
\text { employment generation, social mobilization, Poverty and } \\
\text { Bisweswor Program (5 programs) }\end{array}$ & $\begin{array}{l}\text { 1. Environment: Alternative energy } \\
\text { programs, alternative energy } \\
\text { management fund, agriculture and forest } \\
\text { ( } 3 \text { programs) } \\
\text { 2. Disaster: Disaster and river training } \\
\text { (1 program) }\end{array}$ & $\begin{array}{l}27 \% \text { activities were budgeted. } \\
\text { Unfunded activities: } \\
\text { ODF, biodiversity conservation, } \\
\text { social inclusion were unfunded } \\
\text { activities }\end{array}$ \\
\hline Solukhumbu & $\begin{array}{l}\text { 1. NPC ceiling and document } \\
\text { 2. Interim Plan; policies, circular, Master Plans in different } \\
\text { subjects, and other directives from MoLD and GoN }\end{array}$ & $\begin{array}{l}\text { 1. Environment: Forest management } \\
\text { program, biodiversity conservation, repair, } \\
\text { maintenance and rehabilitation } \\
\text { 2. Sanitation: Sanitation, drinking water }\end{array}$ & $\begin{array}{l}\text { No explicitly described the programs } \\
\text { in the policy documents }\end{array}$ \\
\hline Udaypur & $\begin{array}{l}\text { 1. Environment: alternative energy (micro-hydropower), IEE } \\
\text { for SG\&S, watershed management, forestation program, } \\
\text { churia conservation (5 programs) } \\
\text { 2. Disaster: river control, disasters from flood, landslides } \\
\text { (3 programs) } \\
\text { 3. Sanitation: ODF (1 program) } \\
\text { 4. Social Inclusion: Poverty reduction (1 program) } \\
\end{array}$ & $\begin{array}{l}\text { 1. Environment: Alternative energy } \\
\text { programs, rural electrification, forest } \\
\text { management, environment development } \\
\text { fund, soil conservation and watershed } \\
\text { management (5 programs) } \\
\text { 2. Disaster: River control training, } \\
\text { (1 program) } \\
\text { 3. Sanitation: Open defecation free } \\
\text { campaign and declaration, drinking water, } \\
\text { (2 programs) } \\
\text { 4. Social inclusion: Disadvantaged group } \\
\text { mapping, upliftment, poverty alleviation } \\
\text { fund (2programs) }\end{array}$ & $100 \%$ activities were budgeted. \\
\hline Sarlahi & $\begin{array}{l}\text { 1. Environment Management: Physical infrastructures repair } \\
\text { and maintenance, agriculture, forest and environment, } \\
\text { Churia protection programme, community forestry } \\
\text { cooperative forest, reforestation, environment education } \\
\text { and extension education, lakes, ponds and wetland } \\
\text { conservation, energy and environment unit ( } 6 \text { programs) } \\
\text { 2. Disaster: Control natural calamities, disaster ( } 2 \text { programs) } \\
\text { 3. Sanitation: Drinking water, ODF ( } 2 \text { programs) } \\
\text { 4. Social Inclusion: Poverty, education, health, nutrition, } \\
\text { cleanliness, human resources development, development of } \\
\text { targeted people ( } 4 \text { programs) }\end{array}$ & $\begin{array}{l}\text { 1. Environment: Forest, forest promotion } \\
\text { and environment development fund, } \\
\text { churia conservation, repair, maintenance } \\
\text { and rehabilitation (4 programs) } \\
\text { 2. Disaster: Disaster, river control training } \\
\text { (2 programs) } \\
\text { 3. Sanitation: Open defecation free } \\
\text { campaign and declaration, drinking water } \\
\text { (2 programs) } \\
\text { 4. Social Inclusion: Poverty eradication } \\
\text { and social mobilization, backward, dalit, } \\
\text { poor, muslims, madeshi and indigenous } \\
\text { people, (2 programs) }\end{array}$ & $71 \%$ activities were budgeted. \\
\hline
\end{tabular}


Citation: Raj Sigdel E (2013) Sustainable Energy Maintaining into Local Development Plan in Nepal. J Biodivers Endanger Species 1: 112. doi: 10.4172/2332-2543.1000112

Page 5 of 7

\begin{tabular}{|c|c|c|c|}
\hline Chitwan & $\begin{array}{l}\text { 3. Environment: Alternative energy promotion, organic } \\
\text { farming, forest, soil conservation, watershed management, } \\
\text { Presidential Program on Churia Conservation, climate } \\
\text { change mitigation, District Transport Master Plan } \\
\text { (8 programs) } \\
\text { 2. Disaster: landslides control, river control, water induced } \\
\text { disasters ( } 3 \text { programs) } \\
\text { 3. Sanitation: Model in health and sanitation program, } \\
\text { drinking water supply, ODF, smoke free households } \\
\text { (4 programs) } \\
\text { 4. Social Inclusion: poverty alleviation program (1 program) }\end{array}$ & $\begin{array}{l}\text { 1. Environment: Strengthen energy } \\
\text { unit, repair maintenance special fund, } \\
\text { Repair, maintenance and rehabilitation, } \\
\text { ( } 3 \text { programs) } \\
\text { 2. Sanitation: Sanitation, drinking water } \\
\text { (2 programs) }\end{array}$ & $\begin{array}{l}31 \% \text { activities were budgeted. } \\
\text { Unfunded activities: Churia } \\
\text { Conservation, climate change } \\
\text { mitigation, gender and social } \\
\text { inclusion, ODF }\end{array}$ \\
\hline Rasuwa & $\begin{array}{l}\text { 1. Environment: Climate change and mitigation, repair and } \\
\text { maintenance of fund, greenery along the agricultural road, } \\
\text { climate change, alternative energy ( } 4 \text { programs) } \\
\text { 2. Disaster: disaster management, disaster special fund } \\
\text { ( } 2 \text { programs) } \\
\text { 3. Sanitation: ODF, clean drinking water and sanitation } \\
\text { system ( } 2 \text { programs) } \\
\text { 4. Social Inclusion: Poverty alleviation, women, children, } \\
\text { disabled, indigenous and ethnic people, CFLG, nutrition } \\
\text { improvement, gender sensitive and responsive budget } \\
\text { (4 programs) }\end{array}$ & $\begin{array}{l}\text { 1. Environment: Energy, agriculture, } \\
\text { forest and environment, soil conservation } \\
\text { and watershed management, biodiversity } \\
\text { conservation ( } 5 \text { programs) } \\
\text { 2. Disaster: Water induced disaster } \\
\text { management (1 program) } \\
\text { 3. Sanitation: Sanitation, drinking water } \\
\text { (2 programs) }\end{array}$ & $\begin{array}{l}67 \% \text { activities were budgeted } \\
\text { Unfunded activities: } \\
\text { ODF, climate change, gender and } \\
\text { social inclusion }\end{array}$ \\
\hline Lalitpur & $\begin{array}{l}\text { 1. Environment: watershed management, awareness } 2 \text {. } \\
\text { Sanitation: ODF } 3 \text {. Social Inclusion: poverty alleviation, } \\
\text { social inclusion, indigenous and ethnic people, } \\
\text { disadvantages group ( } 4 \text { programs) }\end{array}$ & $\begin{array}{l}\text { 1. Environment: Alternative energy } \\
\text { programs, soil conservation and } \\
\text { watershed management, environment } \\
\text { friendly infrastructure, } 2 \text {. Sanitation, } \\
\text { drainage and rain water harvest } \\
\text { ( } 4 \text { programs) }\end{array}$ & $\begin{array}{l}100 \% \text { activities were budgeted } \\
\text { Unfunded activities: } \\
\text { ODF, gender and social inclusion }\end{array}$ \\
\hline Manang & $\begin{array}{l}\text { 1. Environment: micro hydro project, environment friendly } \\
\text { motor vehicle, climate change, biodiversity, forest and } \\
\text { Annapurna conservation, waste management ( } 6 \text { programs) } \\
\text { 2. Disaster: River training and protection, water induced } \\
\text { disaster management ( } 2 \text { programs) } \\
\text { 3. Sanitation: Awareness program, drinking water, integrated } \\
\text { water resources management ( } 3 \text { programs) }\end{array}$ & $\begin{array}{l}\text { 1. Environment: Alternative energy } \\
\text { programs, forest management program, } \\
\text { biodiversity conservation, integrated } \\
\text { water resources management, climate } \\
\text { change adaptation ( } 5 \text { programs) } \\
\text { 2. Sanitation: Sanitation, drinking water } \\
\text { (2 programs) } \\
\text { 3. Social inclusion: women and children } \\
\text { program ( } 2 \text { programs) }\end{array}$ & $\begin{array}{l}82 \% \text { activities were budgeted } \\
\text { Unfunded activities: } \\
\text { Disaster management }\end{array}$ \\
\hline Parbat & $\begin{array}{l}\text { 1. Environment: alternative and renewable energy program, } \\
\text { conservation of NTFP, road side plantation, environment } \\
\text { friendly projects ( } 4 \text { programs) } \\
\text { 2. Sanitation: drinking water, sanitation, ODF ( } 3 \text { programs) } \\
\text { 3. Social Inclusion: Uplift economic and social status } \\
\text { of landless and poor, social inclusion, dalit, poor and } \\
\text { Indigenous people special program (3 programs) }\end{array}$ & $\begin{array}{l}\text { 1. Environment: Energy, forest } \\
\text { management program, forest promotion } \\
\text { and environment development fund, } \\
\text { soil conservation and watershed } \\
\text { management, repair, maintenance and } \\
\text { rehabilitation, (5 programs) } \\
\text { 2. Sanitation: Open defecation free, } \\
\text { campaign and declaration, ( } 2 \text { programs) } \\
\text { 3. Social inclusion: Poverty reduction, } \\
\text { poverty alleviation and social mobilization } \\
\text { special fund (2 programs) }\end{array}$ & $\begin{array}{l}70 \% \text { activities were budgeted } \\
\text { Unfunded activities: } \\
\text { Gender and social inclusion }\end{array}$ \\
\hline \multirow[t]{2}{*}{ Nawalparasi } & $\begin{array}{l}\text { 1. Environment: agriculture, forest, alternative energy } \\
\text { promotion, forest, climate change, organic farming, } \\
\text { DTMP based road, road side plantation, carbon trade and } \\
\text { awareness program ( } 9 \text { programs) } \\
\text { 2. Disaster: River bank farming with Jatropha, river bank } \\
\text { control, disaster management and soil conservation } \\
\text { (3 programs) } \\
\text { 3. Sanitation: ODF and total sanitation, health, drinking } \\
\text { water ( } 3 \text { programs) } \\
\text { 4. Social Inclusion: poverty alleviation and social upliftment } \\
\text { with the emphasis on children, women, indigenous people, } \\
\text { madheshis, muslim and other disadvantages groups, DAG } \\
\text { maps ( } 2 \text { programs) }\end{array}$ & $\begin{array}{l}\text { 1. Environment: Alternative energy } \\
\text { programs, agriculture, forest and } \\
\text { environment, soil conservation and } \\
\text { watershed management, ( } 5 \text { programs) } \\
\text { 2. Disaster: Disaster, river bank } \\
\text { protection, disaster management fund, } \\
\text { water induced disaster management } \\
\text { (3 prorgms) } \\
\text { 3. Sanitation: Sanitation, drinking water } \\
(2 \text { programs) }\end{array}$ & $\begin{array}{l}59 \% \text { activities were budgeted } \\
\text { Unfunded activities: } \\
\text { Social inclusion, climate change }\end{array}$ \\
\hline & $\begin{array}{l}\text { 1. Environment: Organic farming, herbs and medicinal } \\
\text { plants "one house one garden", alternative energy, soil } \\
\text { conservation, water resources conservation, climate } \\
\text { change mitigation "one house one compost pit program", } \\
\text { "Banravatabarankosamrakschhyannai haamrojeeban } \\
\text { ho", watershed management, Jumla as plastic fee, waste } \\
\text { management, water mills, micro-hydropower, improved } \\
\text { stoves, solar energy, NTFP (15 programs) } \\
\text { 2. Disaster: river control (1 program) } \\
\text { 3. Sanitation: clean drinking water, sanitation, } \\
\text { "Gharghar ma swotchhacharpi and swotchhadhara, } \\
\text { Jumlasundarbanaunehamroabhibhara" ODF, drainage } \\
\text { management (5 programs) } \\
\text { 4. Social Inclusion: DACAW, Dalit and disadvantaged } \\
\text { groups, social security and child nutrition program } \\
\text { (4 programs) }\end{array}$ & $\begin{array}{l}\text { 1. Environment: Alternative energy } \\
\text { programs, forest management program, } \\
\text { forest promotion and environment } \\
\text { development fund, repair maintenance } \\
\text { special fund (4 programs) } \\
\text { 2. Disaster: Disaster (1 program) } \\
\text { 3. Sanitation: Sanitation, drinking water } \\
\text { (2 programs) } \\
\text { 4. Social inclusion: Backward, Dalit, poor, } \\
\text { Muslims, Madeshi and indigenous people, } \\
\text { District Poverty Monitoring and Analysis } \\
\text { System (DPMAS), social mobilization, } \\
\text { Decentralized Action for Children and } \\
\text { Women Program (DACAW) and Child } \\
\text { Friendly Local Governance (CFLG) } \\
\text { (5 programs) }\end{array}$ & $\begin{array}{l}48 \% \text { activities were budgeted } \\
\text { Unfunded activities: } \\
\text { ODF, NTFP, micro-hydro etc. }\end{array}$ \\
\hline
\end{tabular}


Citation: Raj Sigdel E (2013) Sustainable Energy Maintaining into Local Development Plan in Nepal. J Biodivers Endanger Species 1: 112. doi: 10.4172/2332-2543.1000112

Page 6 of 7

\begin{tabular}{|c|c|c|c|}
\hline Surkhet & $\begin{array}{l}\text { 1. Environment: solid waste, micro-hydropower, forest, } \\
\text { biodiversity, NTFP, churia conservation } \\
\text { (6 programs) } \\
\text { 2. Disaster: bio-engineering, river control } \\
\text { ( } 2 \text { programs) } \\
\text { 3. Sanitation: ODF, drinking water and sanitation program } \\
\text { ( } 3 \text { programs) } \\
4 \text {. Social Inclusion: Create jobs to the poor, indigenous } \\
\text { people, and disadvantaged groups ( } 1 \text { program) }\end{array}$ & $\begin{array}{l}\text { 1. Environment: Strengthen energy unit, } \\
\text { alternative energy programs, alternative } \\
\text { energy management fund, forest } \\
\text { management, Soil conservation and } \\
\text { Watershed Management ( } 5 \text { activities) } \\
\text { 2. Disaster: River bank protection, water } \\
\text { induced disaster management } \\
\text { (2 programs) } \\
\text { 3. Sanitation: Sanitation (1 program) }\end{array}$ & $\begin{array}{l}67 \% \text { activities were budgeted } \\
\text { Unfunded activities: } \\
\text { ODF, NTFP, micro-hydro, social } \\
\text { inclusion etc }\end{array}$ \\
\hline Banke & $\begin{array}{l}\text { 1. Environment: LAPA, DTMP, mitigation of climate } \\
\text { change effect, Churia, Soil Conservation and Watershed } \\
\text { Management Department ( } 5 \text { programs) } \\
\text { 2. Disaster: Disaster Risk Management (1 program)3. } \\
\text { Social Inclusion: social mobilization, training for women, } \\
\text { dalit, indigenous people, madhesis, muslims and all the } \\
\text { disadvantaged groups, DPMAS (3 programs) }\end{array}$ & $\begin{array}{l}\text { 1. Environment: Environment, alternative } \\
\text { energy programs, forest management, } \\
\text { biodiversity conservation (4 programs) } \\
\text { 2. Disaster: Water induced disaster } \\
\text { management (1 program) } \\
\text { 3. Sanitation: Sanitation, drinking water } \\
\text { (2 programs) } \\
\text { 4. Social inclusion: Backward, dalit, } \\
\text { poor, muslims, madeshi and indigenous } \\
\text { people(1 program) }\end{array}$ & $\begin{array}{l}89 \% \text { activities were budgeted } \\
\text { Unfunded activities: } \\
\text { Climate change, Churia } \\
\text { conservation, }\end{array}$ \\
\hline Doti & $\begin{array}{l}\text { 1. Environment: Agriculture, Forest and Environment } \\
\text { Management, biodiversity conservation, solar panel } \\
\text { installation, soil and forest conservation with watershed } \\
\text { management, rural energy, bush fire control ( } 8 \text { programs) } \\
\text { 2. Social Inclusion: poverty alleviation(1 program) } \\
\text { 3. Disaster: Water induced disaster management (1 } \\
\text { program) } \\
\text { 4. Social Inclusion: Women, dalit, senior citizen, children, } \\
\text { Indigenous and ethnic people, disabled people, backward } \\
\text { classes, and disadvantaged groups (1 prorgam) }\end{array}$ & $\begin{array}{l}\text { 1. Disaster: Disaster, water induced } \\
\text { disaster management ( } 2 \text { programs) } \\
\text { 2. Environment: Forest management } \\
\text { program, forest promotion and } \\
\text { environment development fund, } \\
\text { churiaconservation ( } 3 \text { programs) } \\
\text { 3. Sanitation: Open defecation free, } \\
\text { campaign and declaration, drinking water, } \\
\text { public health including public toilets with } \\
\text { water supply (4 programs) } \\
\text { 4. Social inclusion : Disadvantaged group } \\
\text { upliftment, poverty reduction program (2 } \\
\text { programs) }\end{array}$ & $100 \%$ activities were budgeted \\
\hline Kanchanpur & $\begin{array}{l}\text { 1. Environment: climate change mitigation, District Energy } \\
\text { and Environment Unit, biodiversity conservation, churia } \\
\text { conservation, forest, agriculture and livestock development } \\
\text { (6 programs) } \\
\text { 2. Disaster: District Disaster Management Plan, river } \\
\text { protection, river bank protection and water induced disaster } \\
\text { management ( } 4 \text { programs) } \\
\text { 3. Sanitation: ODF (1 program) } \\
\text { 4. Social Inclusion: upliftment of poor, indigenous and } \\
\text { disadvantages people, target program women, children, } \\
\text { backward, disabled, indigenous and ethnic people, dalits, } \\
\text { muslims, and targeted people, capacity development, } \\
\text { employment generation, income generation (3 programs) }\end{array}$ & $\begin{array}{l}\text { 1. Environment: Environment, strengthen } \\
\text { energy unit, alternative energy programs, } \\
\text { forest management program, Forest } \\
\text { Promotion and Environment Development } \\
\text { Fund, churia conservation (6 programs) } \\
\text { 2. Disaster: Disaster, river bank } \\
\text { protection, river control training, disaster } \\
\text { management fund (4 programs) } \\
\text { 3. Sanitation: Sanitation, drinking water } \\
\text { (2 programs) } \\
\text { 4. Social Inclusion: Backward, Dalit, poor, } \\
\text { Muslims, Madeshi and indigenous people } \\
\text { (1 program) }\end{array}$ & $\begin{array}{l}93 \% \text { activities were budgeted } \\
\text { Unfunded activities: } \\
\text { Climate change, biodiversity } \\
\text { conservation }\end{array}$ \\
\hline Dharan & $\begin{array}{l}\text { 1. Environment: mitigate climate change effect, planting } \\
\text { trees, develop garden or macro-parks rain water harvest } \\
\text { in the city, control stray animals, celebrate different world } \\
\text { days and create awareness, Biogas, electrical crematorium } \\
\text { integrated watershed management, waste management } \\
\text { declare Dharan as plastic free. (11 programs) } \\
\text { 2. Sanitation: declare plastic free and ODF. drinking water } \\
\text { sources protection (3 programs) }\end{array}$ & $\begin{array}{l}\text { Environment: Waste management, } \\
\text { Soil conservation and Watershed } \\
\text { Management, ( } 2 \text { programs) } \\
\text { 2. Disaster: Disaster ( } 1 \text { program) } \\
\text { 3. Sanitation: Public health including } \\
\text { public toilets with water supply, } \\
\text { Awareness Program ( } 2 \text { programs) }\end{array}$ & $\begin{array}{l}36 \% \text { activities were budgeted } \\
\text { Unfunded activities: } \\
\text { Climate change, alternative energy }\end{array}$ \\
\hline Madhyapur & $\begin{array}{l}\text { 1. Environment: conservation of religious temple and } \\
\text { ponds, biodiversity conservation, plantation, solid waste } \\
\text { management (4 programs) } \\
\text { 2. Disaster: disaster rescue (1 program) } \\
\text { 3. Sanitation: Water tap management, drainage repair, } \\
\text { cleanliness and sanitation, ODF and people's awareness } \\
\text { would be created by launching various programs (5 } \\
\text { programs) } \\
\text { 4. Social inclusion: poverty reduction, social inclusion } \\
\text { t, cooperation, targeted program would be launched ( } 2 \\
\text { programs) }\end{array}$ & $\begin{array}{l}\text { 1. Environment: Waste management, } \\
\text { Environment, District agricultural road } \\
\text { (3 programs) } \\
\text { 2. Disaster: Disaster rescue, Fire brigade } \\
\text { ( } 2 \text { programs) }\end{array}$ & $\begin{array}{l}42 \% \text { activities were budgeted } \\
\text { Unfunded activities: } \\
\text { Biodiversity conservation, ODF, } \\
\text { social inclusions }\end{array}$ \\
\hline Lekhnath & $\begin{array}{l}\text { 1. Environment: environment friendly road, micro-hydro, } \\
\text { biogas, organic farming, plant protection, biological pest } \\
\text { management, EIA for large infrastructure construction, } \\
\text { community forest, biodiversity, public parks establishments } \\
\text { and plantation, waste management (12 programs) } \\
\text { 2. Sanitation: Drinking water sources protection, public } \\
\text { awareness, Drinking Water Supply and Sanitation, } \\
\text { and sanitation, plastic free and ODF, (5 programs) } 3 \text {. } \\
\text { Social Inclusion: Child friendly, disabled friendly, gender } \\
\text { friendly infrastructures, Dalit, women, children, backward, } \\
\text { indigenous and ethnic (4 programs) }\end{array}$ & $\begin{array}{l}\text { 1. Environment: Waste management, } \\
\text { forest management program, climate } \\
\text { change adaptation, awareness program } \\
\text { ( } 4 \text { programs) } \\
\text { 2. Disaster: Disaster ( } 1 \text { program) }\end{array}$ & $\begin{array}{l}24 \% \text { activities were budgeted } \\
\text { Unfunded activities: } \\
\text { Biogas, micro-hydro, social inclusion }\end{array}$ \\
\hline
\end{tabular}


Citation: Raj Sigdel E (2013) Sustainable Energy Maintaining into Local Development Plan in Nepal. J Biodivers Endanger Species 1: 112. doi: 10.4172/2332-2543.1000112

Page 7 of 7

\begin{tabular}{|c|c|c|c|}
\hline Ghorahi & $\begin{array}{l}\text { 1. Environment: Repair and maintenance fund, solid waste, } \\
\text { plantation, soil conservation, controlled of plastic use below } \\
20 \text { micron, ponds conservation, GIS mapping of the city, } \\
\text { solar power for street lighting ( } 7 \text { programs) } \\
\text { 3. Disaster: riverbank protection, disaster risk management } \\
\text { (2 programs) } \\
\text { 2. Sanitation: drinking water, slaughterhouse, ODF } \\
\text { (3 programs) }\end{array}$ & $\begin{array}{l}\text { 1. Environment: Waste management } \\
\text { (1 program) }\end{array}$ & $\begin{array}{l}9 \% \text { activities were budgeted } \\
\text { Unfunded activities: } \\
\text { Alternative energy, ODF, biodiversity } \\
\text { conservation etc. }\end{array}$ \\
\hline Dhangadi & $\begin{array}{l}\text { 1. Environment: Children parks, waste management } \\
\text { (2 programs) } \\
\text { 2. Disaster: river control, and disaster management } \\
\text { (2 programs) } \\
\text { 3. Sanitation: Slaughter house, sanitation program, toilet } \\
\text { with the slogan of "one house one toilet", ODF (4 programs) } \\
\text { 4. Social inclusion: deprived community focused programs } \\
\text { such as dalits, indigenous and ethnic people, single women, } \\
\text { disabled, threatened tribes and disadvantaged groups } \\
\text { (1 program) }\end{array}$ & $\begin{array}{l}\text { 1. Environment: Forest Management } \\
\text { program, District agricultural road, Repair, } \\
\text { maintenance and rehabilitation, } \\
\text { ( } 3 \text { programs) } \\
\text { 2. Disaster: Disaster (1 program) } \\
\text { 3. Sanitation: Public health including } \\
\text { public toilets with water supply, } \\
(2 \text { program) } \\
\text { 4. Social inclusion: Poverty reduction } \\
\text { program (1 program) }\end{array}$ & $\begin{array}{l}78 \% \text { activities were budgeted } \\
\text { Unfunded activities: } \\
\text { ODF, social inclusion }\end{array}$ \\
\hline
\end{tabular}

